\title{
Investigations on the physical and mechanical behaviour of sycamore maple (Acer pseudoplatanus L.)
}

\author{
Journal Article \\ Author(s): \\ Sonderegger, Walter; Martienssen, Anne; Nitsche, Christiane; Ozyhar, Tomasz; Kaliske, Michael; Niemz, Peter \\ Publication date: \\ 2013-01 \\ Permanent link: \\ https://doi.org/10.3929/ethz-b-000057465 \\ Rights / license: \\ In Copyright - Non-Commercial Use Permitted \\ Originally published in: \\ European Journal of Wood and Wood Products 71(1), https://doi.org/10.1007/s00107-012-0641-8
}




\title{
Investigations on the physical and mechanical behaviour of sycamore maple (Acer pseudoplatanus L.)
}

\author{
Walter Sonderegger - Anne Martienssen • \\ Christiane Nitsche $\cdot$ Tomasz Ozyhar • \\ Michael Kaliske $\cdot$ Peter Niemz
}

Received: 19 March 2012/Published online: 30 October 2012

(c) Springer-Verlag Berlin Heidelberg 2012

\begin{abstract}
Physical and mechanical properties of sycamore maple (Acer pseudoplatanus L.) were extensively investigated as basis for three-dimensional material modelling for structural simulations (e.g., with finite element method) based on this species. The physical properties of swelling, water absorption, water vapour resistance and thermal conductivity were tested and the mechanical properties of tensile, bending and compression strength and of Young's modulus (static and dynamic) as well as of Poisson's ratio, shear strength, shear modulus and fracture toughness were determined. The tests were carried out for most of the features depending on moisture content and also in all three anatomical main directions: longitudinal, radial and tangential.
\end{abstract}

W. Sonderegger · T. Ozyhar · P. Niemz $(\square)$

ETH Zurich, Institute for Building Materials, Wood Physics

Group, Schafmattstrasse 6, 8093 Zurich, Switzerland

e-mail: niemzp@ethz.ch

Present Address:

W. Sonderegger

Neutron Imaging and Activation Group, Paul Scherrer Institut, Villigen, Switzerland

\section{A. Martienssen}

Faculty of Mechanical Science and Engineering, Institute of Wood and Paper Technology,

TU Dresden, Dresden, Germany

C. Nitsche

Wood Engineering, BA Dresden, Dresden, Germany

M. Kaliske

Faculty of Civil Engineering, Institute for Structural Analysis,

TU Dresden, Dresden, Germany
Untersuchungen zum physikalischen und mechanischen Verhalten von Bergahorn (Acer pseudoplatanus L.)

Zusammenfassung Die physikalischen und mechanischen Eigenschaften von Bergahorn (Acer pseudoplatanus L.) wurden eingehend untersucht, um eine Grundlage für eine dreidimensionale Materialmodellierung für Struktursimulationen (z.B. mit der Methode der finiten Elemente), basierend auf dieser Holzart, zu schaffen. Bei den physikalischen Eigenschaften wurden das Quellen, die Wasseraufnahme, der Wasserdampfdiffusionswiderstand und die Wärmeleitfähigkeit geprüft sowie bei den mechanischen Eigenschaften die Zug-, Biege- und Druckfestigkeit, der Elastizitätsmodul (statisch und dynamisch), die Poissonzahl, die Scherfestigkeit, der Schubmodul und die Bruchzähigkeit bestimmt. Die Untersuchungen wurden in den meisten Fällen feuchteabhängig durchgeführt und ebenso in allen drei anatomischen Hauptrichtungen: längs, radial und tangential.

\section{Introduction}

Sycamore or great maple (Acer pseudoplatanus L.) is one of the most common hardwoods in Central Europe. Already, its population in Switzerland adds up to 11.8 Mio $\mathrm{m}^{3}$ according to the Swiss National Forest Inventory (Brändli 2010) and appears on the third position after beech $\left(73.3 \mathrm{Mio} \mathrm{m}^{3}\right)$ and ash $\left(14.8 \mathrm{Mio} \mathrm{m}^{3}\right)$. Due to the successive alteration of the forests culminating in a higher fraction of hardwood, a stronger forestry use of these wood species is required (Krackler et al. 2010).

Therefore, hardwood is among conventional applications like parquetry and interior joinery, furniture- and musical instrument-making more and more applied for wood 
constructions (glulam). Thereby, well-founded knowledge of the material properties of these species is even more necessary, and the calculation and simulation of material behaviour are increasingly carried out with the finite element method (for example, for calculation of boards). Therefore, among the strength properties, the complete elastic parameter set according to the generalised Hooke's law (3 moduli of elasticity (MOE), 3 shear moduli (G) and 6 Poisson's ratios within the three main directions longitudinal (L), radial $(\mathrm{R})$ and tangential $(\mathrm{T})$ ) are required. In addition, the influence of moisture on the elastic and strength parameters has to be evaluated, and heat and moisture transport parameters (sorption, diffusion, thermal conductivity) as well as shrinkage and swelling are required. Analogously, the influences of grain angle (LR, LT) and ring angle (RT) on the parameters mentioned above have to be known. Ideally, also the parameters of the plastic deformation have to be known since this topic is increasingly studied (e.g., Schmidt 2009; Hering 2011). According to Eq. (1), the total strain consists of mechanical stresses and climatically induced stresses and is composed additively:

$\varepsilon_{t o t}=\varepsilon_{e l}+\varepsilon_{m}+\varepsilon_{m s}+\varepsilon_{v e}+\varepsilon_{p l}$

where $\varepsilon_{\mathrm{tot}}$ is the total strain, $\varepsilon_{\mathrm{el}}$ the elastic strain, $\varepsilon_{\mathrm{m}}$ the moisture induced strain, $\varepsilon_{\mathrm{ms}}$ the mechanical-sorptive strain, $\varepsilon_{\mathrm{ve}}$ the viscoelastic strain and $\varepsilon_{\mathrm{pl}}$ the plastic strain.

Altogether, very complex measurements are required to allocate all essential data for a numerical simulation. Supplementary, bonding, surface coating and overlay material as well as defects within the material like cracks and burrowing passages of wood insects influence the material behaviour.

Selected property parameters of hardwood have been published amongst others by Kollmann (1951), Bodig and Jayne (1993), Szalai (1994), Pozgaj et al. (1997), Sell (1997), Wagenführ (2007), Kurjatko (2010) and Ross (2011). But complete data sets for the three main wood directions rarely exist, which are sufficient for static calculations and modulations in wood construction and also for calculations on multi-layered boards, parquet or musical instruments with the finite element method. Mostly, investigations on tension, compression and bending are carried out only parallel to the grain, and the parameters for the other main directions $(\mathrm{R}, \mathrm{T})$ which are required for finite element calculations, as well as the influences of grain and ring angle are lacking. Equally, the influence of the load type (tension, compression, bending) and of MC on the elastic constants and the Poisson's ratio are scarcely investigated. Also for the rheological characteristics (creep, relaxation, mechanical-sorptive effects), the parameters are lacking for most parts. Certainly, Hering (2011) and Ozyhar et al. (2012) recently enforced detailed investigations on beech wood. For softwood, most investigations were carried out on Norway spruce as the most commonly used wood for construction (e.g., Neuhaus 1981). For sycamore maple, Wedel (1964) determined in detail swelling, tension, compression, bending, impact bending and shear properties in fibre direction (Table 1). Popper and Niemz (2009) tested and simulated the sorption of sycamore maple on the basis of the Hailwood-Horrobin model. A detailed description of the applications of sycamore maple is found by Wedel (1964) and Sonnabend (1989, 1990).

The aim of this work is to generate a preferable complete dataset of the physical and mechanical properties of sycamore maple. For the present, the rheological and mechanical-sorptive as well as plastic properties are left out whereupon continuing investigations are intended.

\section{Materials and methods}

\subsection{Material}

All test specimens for the determination of the physical and mechanical properties were cut from logs of a sycamore tree (Acer pseudoplatanus L.) of Eastern Switzerland with

Table 1 Mechanical parameters of sycamore maple in fibre direction from different references

Tab. 1 Mechanische Kennwerte von Bergahorn in Faserrichtung aus verschiedenen Literaturquellen

\begin{tabular}{lllll}
\hline & Kollmann (1951) & Wedel $^{\mathrm{a}}(1964)$ & Sell $^{\mathrm{b}}(1997)$ & Wagenführ $(2007)$ \\
\hline Raw density $\left(\mathrm{kg} / \mathrm{m}^{3}\right)$ & 630 & $600(650)^{\mathrm{c}}$ & $610-660$ & $530-630-790$ \\
Tensile strength $\left(\mathrm{N} / \mathrm{mm}^{2}\right)$ & 80 & $126(131)$ & $80-140$ & $82-114$ \\
Bending strength $\left(\mathrm{N} / \mathrm{mm}^{2}\right)$ & $58-110-162$ & $102(108)$ & $85-135$ & $50-95-140$ \\
Compression strength $\left(\mathrm{N} / \mathrm{mm}^{2}\right)$ & $33-57-83$ & $53(55)$ & $46-62$ & $29-49-72$ \\
MOE $\left(\mathrm{N} / \mathrm{mm}^{2}\right)$ & $6300-9200-14900$ & $10500(10900)$ & $9100-12000$ & $6400-9400-15200$ \\
Impact bending strength $\left(\mathrm{kJ} / \mathrm{m}^{2}\right)$ & 64 & $52(67)$ & 64 & 65 \\
\hline
\end{tabular}

\footnotetext{
${ }^{a}$ Values of Norway maple (Acer platanoides L.) in brackets

${ }^{\mathrm{b}}$ Mixed values from sycamore and Norway maple

${ }^{c}$ Density at normal climate
} 
a mean normal density of $626 \mathrm{~kg} / \mathrm{m}^{3}$ (at a MC of about $12 \%$ ) and oven-dry density of $563 \mathrm{~kg} / \mathrm{m}^{3}$.

The following physical properties were tested:

- Swelling

- Water absorption

- Water vapour resistance

- Thermal conductivity

The following mechanical properties were tested at the climates $20 / 35\left(20{ }^{\circ} \mathrm{C}\right.$ and $35 \%$ relative humidity), 20/65, 20/85 and 20/95:

- Bending strength with static and dynamic MOE

- Tensile strength

- Compression strength

- MOE and Poisson's ratio from tensile and compression tests

- Dynamic MOE and shear modulus

- Shear strength

- Fracture toughness $\mathrm{K}_{\mathrm{IC}}$

\subsection{Methods}

\subsubsection{Determination of the physical properties}

2.2.1.1 Swelling The swelling ratio (differential swelling) was determined in L-, R- and T-directions between the climates 20/35 and 20/93 according to DIN 52184 1979-05. 34 specimens sized $20 \mathrm{~mm}(\mathrm{R}) \times 20 \mathrm{~mm}(\mathrm{~T}) \times 100 \mathrm{~mm}$ (L) were used for the L-direction and 35 specimens sized $50 \mathrm{~mm}(\mathrm{R}) \times 50 \mathrm{~mm}(\mathrm{~T}) \times 10 \mathrm{~mm}(\mathrm{~L})$ for the $\mathrm{R}$ - and T-directions.

2.2.1.2 Water absorption The water absorption coefficient was determined in L-, R- and T-directions on cubes with a side length of $50 \mathrm{~mm}$ according to DIN EN ISO 15148 2003-03 (specimen number see Table 2). Four sides were varnished with a synthetic resin lacquer so that the water absorption took place only in one direction. The specimens were conditioned in normal climate (20/65) prior to the test. Then, the specimens were put on a grid $5 \pm 2 \mathrm{~mm}$ deeply in a water bath and weighed after 5 and $20 \mathrm{~min}$ and 1, 2, 4, 8, 11 and $24 \mathrm{~h}$. Thereof, the water absorption coefficient was determined according to Eq. (2) by means of a linear regression through the measured data (x-values: $\mathrm{t}^{0.5}$, y-values: $\Delta \mathrm{m}$ )

$A_{w}=\frac{\Delta m}{\sqrt{t}}$

$A_{w}$ Water absorption coefficient $\left[\mathrm{kg} /\left(\mathrm{m}^{2} \mathrm{~s}^{0.5}\right)\right]$

$\Delta \mathrm{m}$ Mass gain per face area $\left[\mathrm{kg} / \mathrm{m}^{2}\right]$

t Time [s]
Table 2 Physical properties of sycamore maple Tab. 2 Physikalische Kennwerte von Bergahorn

\begin{tabular}{llrllc}
\hline & Direction & No. & $\begin{array}{l}\rho \\
\left(\mathrm{kg} / \mathrm{m}^{3}\right)\end{array}$ & $\begin{array}{l}\text { Mean } \\
\text { value }\end{array}$ & $\mathrm{V}(\%)$ \\
\hline $\mathrm{q}(\% / \%)$ & $\mathrm{L}$ & 34 & 610 & 0.01 & 42 \\
& $\mathrm{R}$ & 35 & 600 & 0.20 & 12 \\
& $\mathrm{~T}$ & 35 & 600 & 0.37 & 9.7 \\
$\mu_{\text {dry }}(-)$ & $\mathrm{R}$ & 6 & 620 & 45 & 2.1 \\
& $\mathrm{~T}$ & 6 & 620 & 103 & 4.0 \\
$\mu_{\text {wet }}(-)$ & $\mathrm{R}$ & 6 & 630 & 15 & 2.8 \\
& $\mathrm{~T}$ & 6 & 620 & 28 & 4.6 \\
$\mathrm{~A}_{\mathrm{w}}\left[\mathrm{kg} /\left(\mathrm{m}^{2} \mathrm{~s}^{0.5}\right)\right]$ & $\mathrm{L}$ & 14 & 600 & 0.054 & 25 \\
& $\mathrm{R}$ & 15 & 600 & 0.0032 & 9.9 \\
& $\mathrm{~T}$ & 17 & 600 & 0.0023 & 18 \\
$\lambda_{10}[\mathrm{~W} /(\mathrm{m} \mathrm{K})]$ & - & 4 & 650 & 0.143 & 6.9 \\
\hline
\end{tabular}

$q$ swelling ratio, $\mu_{d r y}, \mu_{w e t}$ water vapour resistance factors at dry and wet conditions, $A_{w}$ water absorption coefficient, $\lambda_{10}$ thermal conductivity at $10{ }^{\circ} \mathrm{C}, L$ longitudinal, $R$ radial, $T$ tangential, $V$ coefficient of variation, $\rho$ density (climate: $20 / 65$ )

$q$ differentielle Quellung, $\mu_{d r y}, \mu_{w e t}$ Wasserdampfdiffusionswiderstandszahlen im trockenen (dry) und feuchten (wet) Bereich, $A_{w}$ Wasseraufnahmekoeffizient, $\lambda_{10}$ Wärmeleitfähigkeit bei $10^{\circ} \mathrm{C}, L$ in Faserrichtung, $R$ radial, $T$ tangential, $V$ Variationskoeffizient, $\rho$ Rohdichte (Klima: 20/65)

2.2.1.3 Water vapour resistance The water vapour resistance factor was determined according to DIN EN ISO 12572 2001-09 in $\mathrm{R}$ - and T-direction at dry $\left(20{ }^{\circ} \mathrm{C}-65 /\right.$ $0 \% \mathrm{RH})$ and wet $\left(20^{\circ} \mathrm{C}-65 / 100 \% \mathrm{RH}\right)$ conditions. Six specimens with a cross-section of $140 \mathrm{~mm}$ and a thickness of $20 \mathrm{~mm}$ were tested per climate and direction.

2.2.1.4 Thermal conductivity Thermal conductivity was tested perpendicular to the grain on four solid-wood boards (size: $500 \times 500 \times 20 \mathrm{~mm}$ ) with the guarded hot plate apparatus $\lambda$-Meter EP500 (Lambda-Messtechnik GmbH, Dresden) according to ISO 8302 (1991). The specimens were conditioned at the climates 20/35, 20/65, 20/85, 20/95 and oven-dried. After each conditioning, thermal conductivity was measured at three temperatures $(10,20$ and $30{ }^{\circ} \mathrm{C}$ ) each with a temperature difference of $10 \mathrm{~K}$ between the hot and the cold plate and a surface pressure of $2,500 \mathrm{~N} / \mathrm{m}^{2}$. The fitted thermal conductivity at $10^{\circ} \mathrm{C}$ was then determined by the evaluation software EP 500_PC 5.14 with a linear regression through the values at the three temperatures.

\subsubsection{Determination of the mechanical properties}

2.2.2.1 Bending strength and static and dynamic MOE Bending strength and static modulus of elasticity (MOE) were determined according to DIN 52186 1978-06 on 18-26 specimens sized $20 \mathrm{~mm} \quad(\mathrm{R}) \times 20 \mathrm{~mm}$ 
(T) $\times 400 \mathrm{~mm}(\mathrm{~L})$. Previously, sound velocity and eigenfrequency were tested on the same specimens using an ultrasound device (BP-V, $50 \mathrm{kHz}$, Steinkamp, Bremen) and an impulse excitation tester (Grindosonic MK 5 'Industrial', Lemmens N. V., Belgium). Then, the dynamic MOE was calculated from sound velocity (c) and density $(\rho)$ with the basic relation:

$E=\rho \cdot c^{2}$

and from eigenfrequency (first flexural mode) according to the method of Görlacher (1984).

2.2.2.2 Tensile strength Tensile strength was determined parallel to the grain according to DIN 52187 1979-05. Perpendicular to the grain, $95 \mathrm{~mm}$ long dog-bone-shaped specimens (cross-sectional area: max. $28 \times 28 \mathrm{~mm}$, min. $14 \times 14 \mathrm{~mm}$ ) were used according to Hering et al. (2012). 13-16 specimens were tested per direction and climate.

2.2.2.3 Compression strength Compression strength parallel to the grain was determined according to DIN 52185 1976-09 and perpendicular to the grain according to DIN 52192 1979-05. Deviating from the norm, reduced specimen size $(15 \times 15 \times 45 \mathrm{~mm})$ was employed. 16-21 specimens were tested per direction and climate.

2.2.2.4 MOE and Poisson's ratio from tensile and compression tests MOE and Poisson's ratio were determined on the tensile and compression test specimens by means of a video image correlation system (Vic 2D, LIMESS Messtechnik und Software GmbH, Krefeld) for the determination of the longitudinal and transverse elongation. The method is described in detail by Keunecke et al. (2008) and Hering et al. (2012). The Poisson's ratio was determined according to

$\mu_{i j}=-\frac{\varepsilon_{i}}{\varepsilon_{j}}$

where $\mu_{\mathrm{ij}}$ is Poisson's ratio, $\varepsilon_{\mathrm{i}}$ the transverse elongation and $\varepsilon_{\mathrm{j}}$ the longitudinal elongation.

2.2.2.5 Dynamic MOE and shear modulus Dynamic MOE and shear modulus were determined on cubes with a side length of $10 \mathrm{~mm}$ by means of ultrasound. 36-42 specimens were tested per climate. The tests were carried out using an Epoch XT device (Olympus NDT Inc., USA) with an Olympus A133S transducer $(2.27 \mathrm{MHz})$ for longitudinal waves (determination of MOE) and a Staveley S-0104 transducer $(1 \mathrm{MHz})$ for transverse waves (determination of $\mathrm{G}$ ) and the coupling agent Ultragel II (Sonotech, USA). The MOE was determined according to Eq. (3) and the shear modulus $(\mathrm{G})$ according to
$G_{i j}=c_{i j}^{2} \cdot \rho$

where $\mathrm{c}$ is the sound velocity and $\rho$ the density. Thereby, as for the calculation of $\mathrm{G}$ from sound velocity, the directions of wave propagation (first index) and oscillation (second index) are exchangeable for an orthotropic material, the values of $G_{i j}$ and $G_{j i}$ were averaged. For more details see Keunecke et al. (2007).

2.2.2.6 Shear strength Shear strength was tested parallel (shearing planes: LT, LR) and perpendicular to the grain (shearing planes: RL, TL) on cubes with a side length of $50 \mathrm{~mm}$ according to DIN 52187 1979-05. 8-10 specimens were tested per direction and climate.

2.2.2.7 Fracture toughness $K_{I C}$ Fracture toughness $\mathrm{K}_{\mathrm{IC}}$ was determined according to DIN EN ISO 12737 2011-04 on compact specimens at RL, TL, RT and TR directions (first index $=$ direction normal to the crack plane, second index $=$ direction of crack propagation). 5-14 specimens were tested per direction and climate.

The static tests were carried out with a Zwick Z010 universal testing machine (Zwick GmbH \& Co. KG, Ulm) for tension and compression perpendicular to the grain as well as fracture toughness and a Zwick Z100 machine for tension, bending and compression parallel to the grain as well as shearing.

\section{Results and discussion}

\subsection{Physical properties}

The physical properties of sycamore maple are shown in Table 2.

\subsubsection{Swelling}

Differential swelling was determined for the directions $\mathrm{L}: \mathrm{R}: \mathrm{T}$ at a ratio of $1: 20: 37$. Perpendicular to the grain, the values are about one-third higher than literature data. Sell (1997), for example, stated $0.15 \% / \%$ for $\mathrm{R}$ and $0.27 \% / \%$ for $\mathrm{T}$ which are similar to the values of Wagenführ (2007). This demonstrates the high natural variability of this species.

\subsubsection{Water absorption}

The water absorption coefficient is highly influenced by the direction. Parallel to the fibre, the measured value is 24 times higher than in T-direction and 16 times higher than in $\mathrm{R}$-direction. Whereas the values perpendicular to the grain are similar to the values of other hardwoods like beech or 
ash, the value in fibre direction is two to four times higher (Sonderegger et al. 2012). Perpendicular to the grain, the water absorption coefficient is higher in R-direction than in $\mathrm{T}$-direction what is mainly influenced by the rays.

\subsubsection{Water vapour resistance}

The water vapour resistance factor is highly influenced by the direction and is in T-direction twice as high as in R-direction both at dry and wet conditions (Table 2). This may be attributed to the influence of the rays in the R-direction. At dry conditions, the value in both directions is about thrice as high than at wet conditions.

\subsubsection{Thermal conductivity}

The thermal conductivity perpendicular to the grain accounts for $0.143 \mathrm{~W} /(\mathrm{m} \mathrm{K})$ at $10{ }^{\circ} \mathrm{C}$ after conditioning at normal climate (20/65) and is slightly lower than the value in Kollmann (1951) for wood in general at a density of $650 \mathrm{~kg} / \mathrm{m}^{3}$ and clearly lower than the values of maple in Sell (1997) with $0.16-0.18 \mathrm{~W} /(\mathrm{m} \mathrm{K})$. The thermal conductivity increases with increasing temperature at about $0.3 \%$ per $1 \mathrm{~K}$ and with increasing $\mathrm{MC}$ at about $1.4 \%$ per $1 \%$ MC change (Fig. 1).

\subsection{Mechanical properties}

\subsubsection{Tensile, bending and compression tests}

Table 3 and Figs. 2 and 3 show the test results. The strength is highly influenced both by the test mode and the wood direction. Parallel to the fibre, the ratio of tensile strength to bending and compression strength is at normal

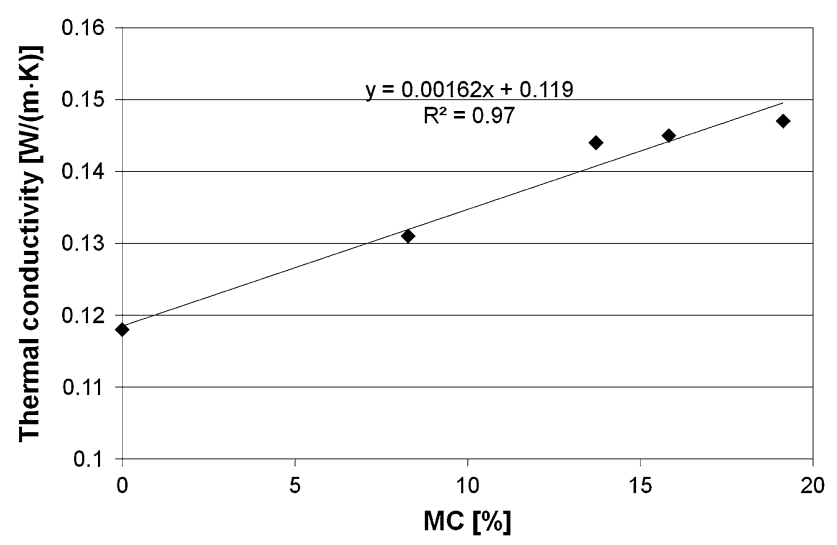

Fig. 1 Thermal conductivity perpendicular to the grain depending on moisture content (MC)

Abb. 1 Wärmeleitfähigkeit senkrecht zur Faserrichtung in Abhängigkeit von der Holzfeuchte (MC) climate about 1.8:1.7:1 and corresponds well with the literature data of Table 1. The influence of MC within the tested RH-range is least for tensile strength (reduction of about $10 \%$ ) whereas bending strength is reduced by about one-third and compression strength by about $40 \%$ (Fig. 2a). Perpendicular to the grain, in contrast only small differences exist between tensile and compression strength. All values are reduced with increasing MC by about onethird (Fig. 2b). For the wood directions at normal climate, the strength ratio of $\mathrm{L}, \mathrm{R}, \mathrm{T}$ is 13:1.8:1 for tension and for compression it is $6: 1.5: 1$.

In contrast to strength, the MOEs parallel to the fibre show rather different ratios with regard to the test mode (Fig. 3a). The highest MOE was determined at compression whereas bending MOEs were similar to tensile MOEs except for the climate 20/35. An explanation of the high compression MOE may be the influence of the bimodularity of the material (Conners and Medvecz 1992) which

Table 3 Mechanical properties of sycamore maple at climate 20/65 Tab. 3 Mechanische Kennwerte von Bergahorn bei Klima 20/65

\begin{tabular}{|c|c|c|c|c|c|}
\hline & Direction & No. & $\rho\left(\mathrm{kg} / \mathrm{m}^{3}\right)$ & Mean value & $\mathrm{V}(\%)$ \\
\hline \multirow[t]{3}{*}{$\sigma_{\mathrm{t}}\left(\mathrm{N} / \mathrm{mm}^{2}\right)$} & $\mathrm{L}$ & 15 & 630 & 112 & 20 \\
\hline & $\mathrm{R}$ & 14 & 630 & 16.2 & 8.8 \\
\hline & $\mathrm{T}$ & 15 & 630 & 8.9 & 7.2 \\
\hline$\sigma_{\mathrm{b}}\left(\mathrm{N} / \mathrm{mm}^{2}\right)$ & $\mathrm{L}$ & 18 & 630 & 102 & 7.8 \\
\hline \multirow[t]{3}{*}{$\sigma_{\mathrm{c}}\left(\mathrm{N} / \mathrm{mm}^{2}\right)$} & $\mathrm{L}$ & 19 & 660 & 61.5 & 6.1 \\
\hline & $\mathrm{R}$ & 16 & 660 & 15.4 & 4.7 \\
\hline & $\mathrm{T}$ & 21 & 660 & 10.3 & 5.4 \\
\hline \multirow[t]{3}{*}{$\operatorname{MOE}_{t}\left(\mathrm{~N} / \mathrm{mm}^{2}\right)$} & $\mathrm{L}$ & 15 & 630 & 11,500 & 24 \\
\hline & $\mathrm{R}$ & 15 & 630 & 1,210 & 10 \\
\hline & $\mathrm{T}$ & 15 & 630 & 690 & 3.8 \\
\hline $\operatorname{MOE}_{b}\left(\mathrm{~N} / \mathrm{mm}^{2}\right)$ & $\mathrm{L}$ & 18 & 630 & 10,900 & 16 \\
\hline \multirow[t]{3}{*}{$\operatorname{MOE}_{\mathrm{c}}\left(\mathrm{N} / \mathrm{mm}^{2}\right)$} & $\mathrm{L}$ & 15 & 660 & 14,500 & 22 \\
\hline & $\mathrm{R}$ & 19 & 660 & 1,140 & 15 \\
\hline & $\mathrm{T}$ & 16 & 660 & 790 & 3.9 \\
\hline \multirow[t]{4}{*}{$\tau\left(\mathrm{N} / \mathrm{mm}^{2}\right)$} & $\mathrm{LT}$ & 10 & 630 & 17.9 & 5.6 \\
\hline & LR & 9 & 610 & 14.3 & 2.0 \\
\hline & RL & 9 & 650 & 7.3 & 12 \\
\hline & $\mathrm{TL}$ & 9 & 590 & 6.6 & 11 \\
\hline \multirow[t]{4}{*}{$\mathrm{K}_{\mathrm{IC}}\left(\mathrm{MPa} \mathrm{m^{0.5 }}\right)$} & RL & 6 & 670 & 1.08 & 18 \\
\hline & TL & 9 & 620 & 0.70 & 11 \\
\hline & RT & 6 & 690 & 0.91 & 11 \\
\hline & TR & 7 & 590 & 0.54 & 17 \\
\hline
\end{tabular}

$\sigma$ strength in tension (t), bending (b) and compression (c), MOE modulus of elasticity, $\tau$ shear strength, $K_{I C}$ critical stress intensity factor, $L$ longitudinal, $R$ radial, $T$ tangential, $\rho$ density, $V$ coefficient of variation

$\sigma$ Festigkeit bei Zug (t), Biegung (b) und Druck (c), MOE Elastizitätsmodul, $\tau$ Scherfestigkeit, $K_{I C}$ Bruchzähigkeit, $L$ in Faserrichtung, $R$ radial, $T$ tangential, $\rho$ Rohdichte, $V$ Variationskoeffizient 

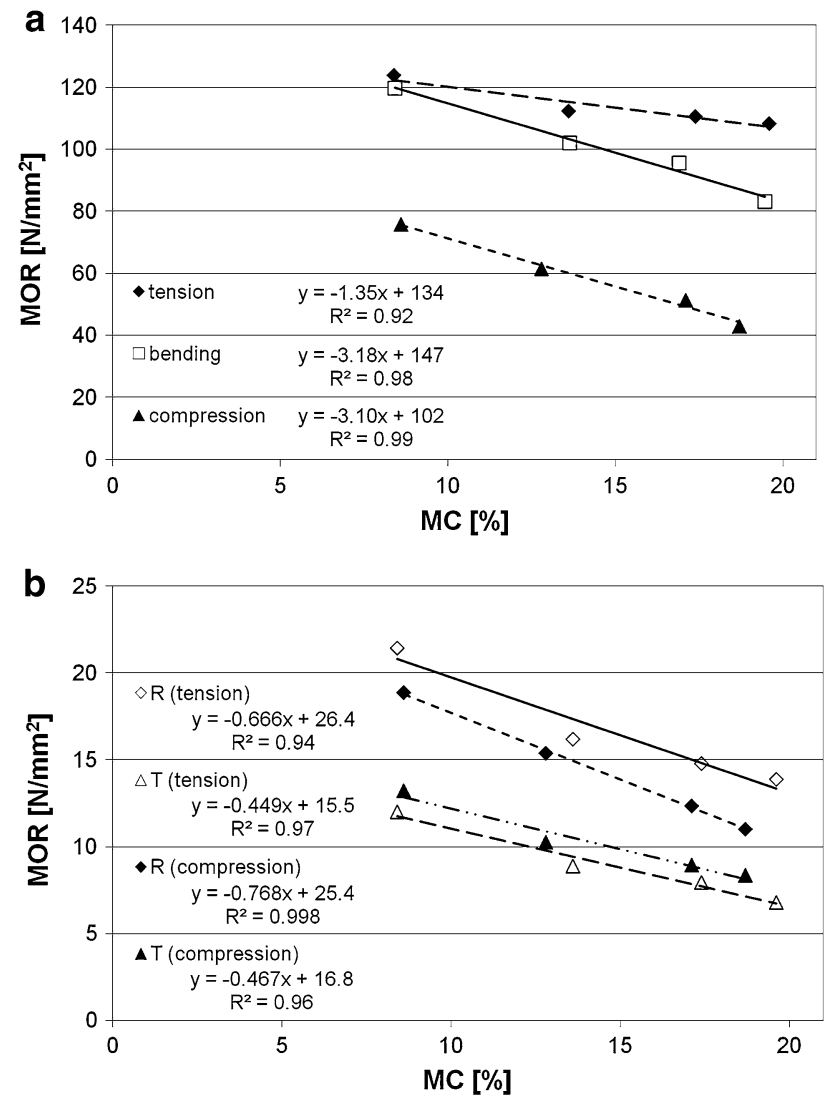

Fig. 2 MOR in L-direction (a) and in R- and T-direction (b) depending on moisture content (MC)

Abb. 2 Festigkeiten (MOR) in L-Richtung (a) sowie in R- und T-Richtung (b) in Abhängigkeit von der Holzfeuchte (MC)

differs according to the wood species. Conners and Medvecz (1992) show similar behaviour for yellow poplar where the compression MOE (in contrast to the tensile MOE) increases from 6 to $12 \% \mathrm{MC}$ and exceeds the tensile MOE by between 6 and $18 \%$ MC. The dynamic MOEs determined from eigenfrequency and sound velocity are clearly higher with a ratio of 1.17 and 1.36 , respectively (mean value over all climates) compared to bending MOE. This effect is amongst others influenced by the wood species and wood quality. The ratios are slightly higher than the ones determined for different hardwoods and softwoods in Niemz et al. (1997). For the MOE determined from sound velocity $(2.27 \mathrm{MHz})$ on the cubic specimens, the ratio was again clearly higher with 1.61 . The influence of MC on MOE is with the exception of tension lower compared to strength. For bending and compression, the MOE remains constant or even increases with increasing MC until a climate of 20/85. Perpendicular to the grain, there are only small differences between
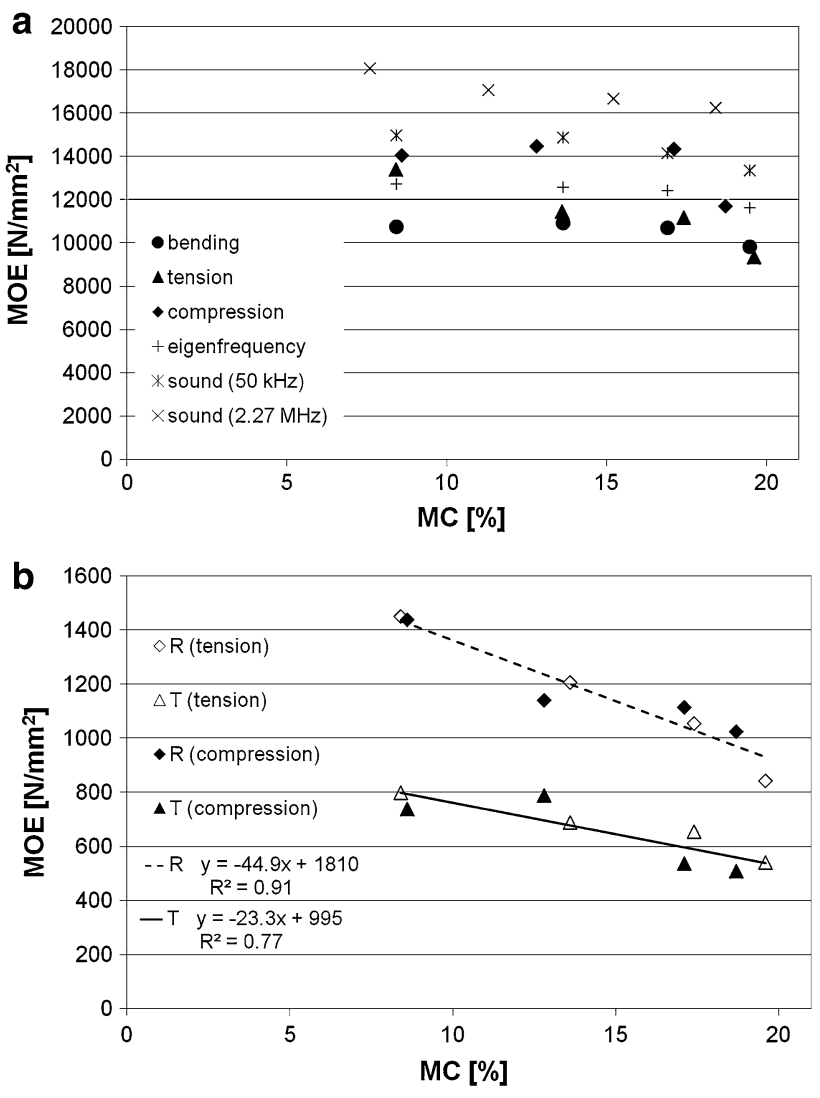

Fig. 3 Modulus of elasticity (MOE) in L-direction (a) and in R- and T-direction (b) depending on moisture content (MC)

Abb. 3 Elastizitätsmodul (MOE) in L-Richtung (a) sowie in R- und T-Richtung (b) in Abhängigkeit von der Holzfeuchte (MC)

Table 4 Modulus of elasticity (MOE) and shear modulus (G) at normal climate (20/65) calculated from ultrasound of cubic specimens and its sensitivity from MC $(\omega)$ according to equation MOE (or $\mathrm{G})=\mathrm{A}+\mathrm{B} \cdot \omega$

Tab. 4 E-Modul (MOE) und G-Modul (G) im Normalklima (20/65) ermittelt aus Ultraschallmessungen an Würfelproben sowie deren Abhängigkeit von der Holzfeuchte $(\omega)$ gemäß der Gleichung MOE (bzw. G) $=\mathrm{A}+\mathrm{B} \cdot \omega$

\begin{tabular}{rlrrrrr}
\hline & Direction & $\begin{array}{l}\text { Moduli }(\mathrm{N} / \\
\left.\mathrm{mm}^{2}\right)\end{array}$ & \multicolumn{1}{l}{$\begin{array}{l}\text { V } \\
(\%)\end{array}$} & & \multicolumn{1}{l}{$\mathrm{B}$} & $\mathrm{R}^{2}$ \\
\hline MOE & $\mathrm{L}$ & 17,100 & 3.7 & 19,100 & -160 & 0.95 \\
& $\mathrm{R}$ & 2,910 & 7.6 & 3,610 & -58.1 & 0.96 \\
& $\mathrm{~T}$ & 1,740 & 10.4 & 2,030 & -24.2 & 0.98 \\
$\mathrm{G}$ & LR & 1,680 & 14.6 & 1,720 & -10.9 & 0.43 \\
& LT & 1,070 & 12.0 & 1,150 & -7.69 & 0.85 \\
& RT & 366 & 9.8 & 414 & -4.68 & 0.97 \\
\hline
\end{tabular}

$A, B$ parameters, $V$ coefficient of variation, $R^{2}$ coefficient of determination

$A$, $B$ Parameter, $V$ Variationskoeffizient, $R^{2}$ Bestimmtheitsmaß 


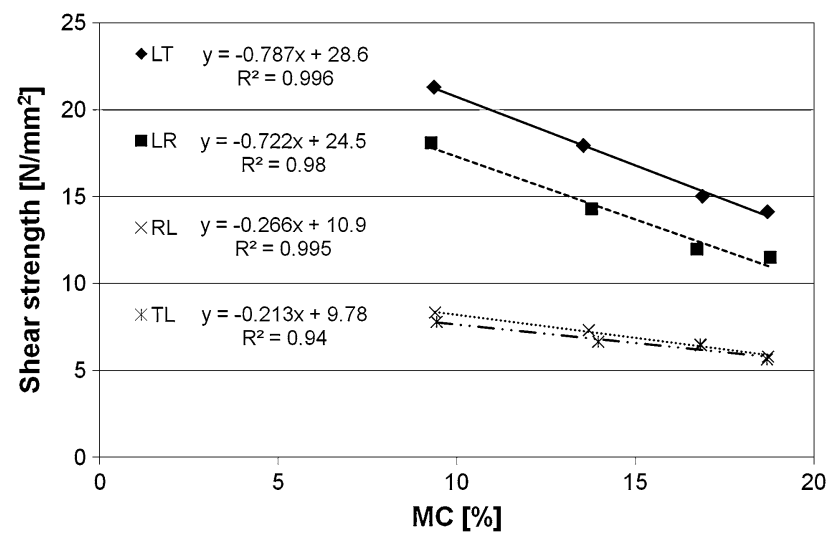

Fig. 4 Shear strength depending on moisture content (MC) Abb. 4 Scherfestigkeit in Abhängigkeit von der Holzfeuchte (MC)

tensile and compression MOE (Fig. 3b). The decrease of MOE with increasing MC is similar to the decrease in strength.

\subsubsection{Dynamic MOE and shear modulus}

Table 4 shows the dynamic MOE and shear moduli determined from the sound velocities on the cubic specimens. Whereas the MOEs in all directions have clearly higher values (up to 2.5 times higher) than the MOEs of the static tests (due to the specimen size and height of the test frequency as well as the non-consideration of the lateral contraction influence), the shear moduli are arranged within the expectancy range. Hering et al. (2012) described similar effects on beech wood. The ratio of the MOEs in the directions L:R:T account for 9.8:1.7:1 and of the shear moduli in the shearing planes LT:LR:RT for 4.5:2.9:1. Thereby, the clearly higher values in R-direction than in
T-direction can be attributed to the reinforcing effect of the rays.

\subsubsection{Shear strength}

The shear strength depends strongly on the test direction (Table 3). Parallel to the grain, the values were two to three times higher than perpendicular to the grain and in the LTplane clearly higher than in the LR-plane. Perpendicular to the grain, the values of the two measured shearing planes hardly differ. Hering (2011) measured similar values by trend but all in all slightly smaller values for beech wood. For all tested directions, a strong correlation exists between shear strength and MC. Thereby, shear strength decreases with increasing MC stronger parallel to the grain than perpendicular to the grain (Fig. 4).

\subsubsection{Poisson's ratio}

Table 5 shows the Poisson's ratio $(\mu)$ at normal climate (20/65) determined from the tension and compression tests, the dependence on $\mathrm{MC}$ by means of a linear regression and comparative literature data. At normal climate, the values from the tension and compression tests differ only little except for the RL and LR directions. The mean Poisson's ratios from tension and compression over all climates coincide quite well with values determined by Stamer and Sieglerschmidt in Kollmann (1951) for sycamore maple and with values of Bodig and Jayne (1993) for hardwood. The influence of MC on Poisson's ratio is not uniform so that the values increase or decrease depending on the direction. Certainly, the coefficient of determination is partially very small too. In contrast, Hering et al. (2012) observed for beech a decrease of Poisson's ratio with increasing $\mathrm{MC}$ in all directions.

Table 5 Poisson's ratio $(\mu)$ at normal climate (20/65) for tension and compression and its sensitivity from MC $(\omega)$ according to equation $\mu=\mathrm{A}+\mathrm{B} \cdot \omega$

Tab. 5 Poissonzahlen $(\mu)$ im Normalklima (20/65) für Zug und Druck sowie deren Abhängigkeit von der Holzfeuchte $(\omega)$ gemäß der Gleichung $\mu=\mathrm{A}+\mathrm{B} \cdot \omega$

\begin{tabular}{|c|c|c|c|c|c|c|c|c|c|c|c|c|c|}
\hline \multirow[b]{2}{*}{ Direction } & \multicolumn{5}{|c|}{ Tension } & \multicolumn{5}{|c|}{ Compression } & \multirow{2}{*}{$\begin{array}{l}\text { Mean } \\
\mu(-)\end{array}$} & \multicolumn{2}{|c|}{ Literature data } \\
\hline & $\mu[-]$ & $\mathrm{V}(\%)$ & A & B & $\mathrm{R}^{2}$ & $\mu(-)$ & $\mathrm{V}(\%)$ & A & B & $\mathrm{R}^{2}$ & & $\mu^{\mathrm{a}}(-)$ & $\mu^{\mathrm{b}}(-)$ \\
\hline RL & 0.49 & 15 & 0.502 & -0.0013 & 0.20 & 0.34 & 44 & 0.276 & 0.0060 & 0.22 & 0.42 & 0.49 & 0.37 \\
\hline $\mathrm{TL}$ & - & - & - & - & - & 0.42 & 31 & 0.470 & -0.0022 & 0.32 & 0.44 & 0.47 & 0.50 \\
\hline TR & 0.65 & 4.3 & 0.434 & 0.0168 & 0.98 & 0.68 & 11 & 0.594 & 0.0071 & 0.98 & 0.69 & 0.76 & 0.67 \\
\hline LR & 0.059 & 36 & 0.048 & 0.0010 & 0.93 & 0.16 & 32 & 0.239 & -0.0082 & 0.74 & 0.091 & 0.074 & 0.044 \\
\hline RT & 0.38 & 9.7 & 0.312 & 0.0049 & 0.97 & 0.40 & 6.9 & 0.411 & -0.0013 & 0.31 & 0.39 & 0.44 & 0.33 \\
\hline LT & 0.043 & 30 & 0.056 & -0.0010 & 0.83 & 0.049 & 53 & 0.161 & -0.0055 & 0.46 & 0.061 & 0.041 & 0.027 \\
\hline
\end{tabular}

$A, B$ parameters, $V$ coefficient of variation, $R^{2}$ coefficient of determination

$A, B$ Parameter, $V$ Variationskoeffizient, $R^{2}$ Bestimmtheitsmaß

${ }^{a}$ Sycamore maple $(\mathrm{MC}=9.6)$ : Stamer and Sieglerschmidt in Kollmann (1951)

b Hardwood: Bodig and Jayne (1993) 


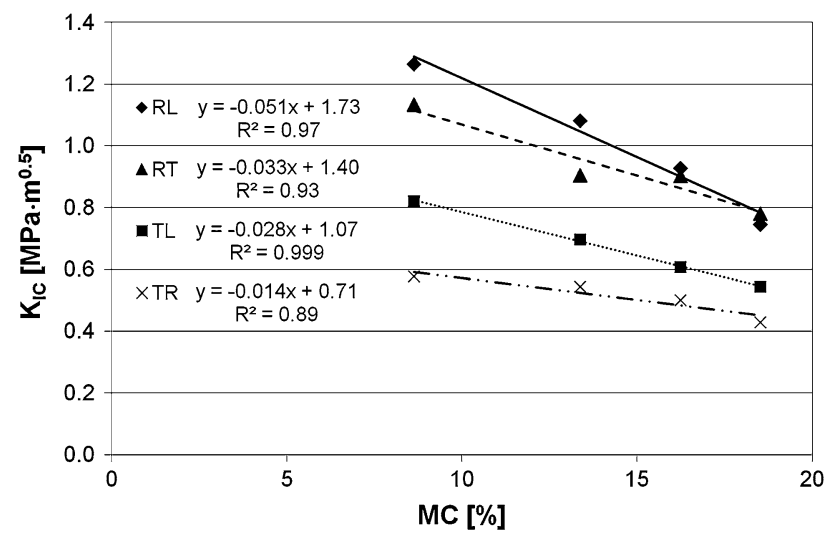

Fig. 5 Fracture toughness $\left(\mathrm{K}_{\mathrm{IC}}\right)$ depending on moisture content (MC) Abb. 5 Bruchzähigkeit $\left(\mathrm{K}_{\mathrm{IC}}\right)$ in Abhängigkeit von der Holzfeuchte (MC)

\subsubsection{Fracture toughness}

Table 3 shows the fracture toughness $\mathrm{K}_{\mathrm{IC}}$ of the different loads at climate $20 / 65$. The values are very high compared with other wood species like oak and beech and also higher compared to sugar maple (Stanzl-Tschegg et al. 2011) and are in the RL and TL directions similar to ash (Reiterer et al. 2002). The tests in the RL and RT directions result in clearly higher values compared to the TL and TR directions which can be attributed to the influence of the rays. The fracture toughness within a crack plane was higher for a crack propagation in fibre direction than perpendicular to the grain what is in contrast with the behaviour of different soft woods (Stanzl-Tschegg et al. 2011). All $\mathrm{K}_{\mathrm{IC}}$ values are highly influenced by MC with the highest percentage decrease in the RL and TL directions (Fig. 5). In contrast, Logemann and Schelling (1992) found only a low influence of MC for spruce in the TL direction.

\section{Conclusion}

A broad dataset of physical and mechanical properties in the three main directions was established for the wood of sycamore maple. Up to now, such complex datasets for hardwoods have been hardly available but become more and more important parallel to the increasing silvicultural availability of these species. The dataset allows within the elastic range the calculation and simulation of multi-layered and three-dimensional wood structures with finite element methods. Still, investigations have to be carried out to determine the rheological properties and the mechanical-sorptive behaviour. Equally, further research is needed to analyse the plastic behaviour which particularly is important by compression perpendicular to the fibre.
Investigations by Hering (2011) and Schmidt (2009) could provide a basis.

Acknowledgments The authors thank the Händel-Haus foundation, Halle for the co-financing of this work.

\section{References}

Bodig J, Jayne B (1993) Mechanics of wood and wood composites, 2nd edn. Krieger Publishing, Malabar

Brändli U-B (ed.) (2010) Schweizerisches Landesforstinventar. Ergebnisse der dritten Erhebung 2004-2006, Eidgenössische Forschungsanstalt für Wald, Schnee und Landschaft WSL, Birmensdorf and Bundesamt für Umwelt (BAFU), Bern

Conners TE, Medvecz PJ (1992) Wood as a bimodular material. Wood Fiber Sci 24(4):413-423

DIN 52184 (1979) Prüfung von Holz; Bestimmung der Quellung und Schwindung. DIN Deutsches Institut für Normung e. V

DIN 52185 (1976) Prüfung von Holz; Bestimmung der Druckfestigkeit parallel zur Faser. DIN Deutsches Institut für Normung e. V

DIN 52186 (1978) Prüfung von Holz; Biegeversuch. DIN Deutsches Institut für Normung e. V

DIN 52187 (1979) Prüfung von Holz; Bestimmung der Scherfestigkeit in Faserrichtung. DIN Deutsches Institut für Normung e. $\mathrm{V}$

DIN 52192 (1979) Prüfung von Holz; Druckversuch quer zur Faserrichtung. DIN Deutsches Institut für Normung e. V

DIN EN ISO 12572 (2001) Wärme- und feuchtetechnisches Verhalten von Baustoffen und Bauprodukten - Bestimmung der Wasserdampfdurchlässigkeit. DIN Deutsches Institut für Normung e. V

DIN EN ISO 12737 (2011) Metallische Werkstoffe - Bestimmung der Bruchzähigkeit (ebener Dehnungszustand). DIN Deutsches Institut für Normung e. V

DIN EN ISO 15148 (2003) Hygrothermal performance of building materials and products-Determination of water absorption coefficient by partial immersion. DIN Deutsches Institut für Normung e. V

Görlacher R (1984) Ein neues Messverfahren zur Bestimmung des Elastizitätsmoduls von Holz. Holz Roh-Werkst 42(6):219-222

Hering S (2011) Charakterisierung und Modellierung der Materialeigenschaften von Rotbuchenholz zur Simulation von Holzverklebungen. Dissertation, ETH Zürich

Hering S, Keunecke D, Niemz P (2012) Moisture-dependent orthotropic elasticity of beech wood. Wood Sci Technol (online first). doi:10.1007/s00226-011-0449-4

ISO 8302 (1991) Thermal insulation; determination of steady-state thermal resistance and related properties; guarded hot plate apparatus. ISO International Organization for Standardization

Keunecke D, Sonderegger W, Pereteanu K, Lüthi T, Niemz P (2007) Determination of Young's and shear moduli of common yew and Norway spruce by means of ultrasonic waves. Wood Sci Technol 41(4):309-327

Keunecke D, Hering S, Niemz P (2008) Three-dimensional elastic behaviour of common yew and Norway spruce. Wood Sci Technol 42(8):633-647

Kollmann F (1951) Technologie des Holzes und der Holzwerkstoffe, vol 1, 2nd edn. Springer, Berlin

Krackler V, Keunecke D, Niemz P (2010) Verarbeitung und Verwendungsmöglichkeiten von Laubholz und Laubholzresten. ETH Zürich, Eigenverlag

Kurjatko S (2010) Parameters to qualify wood relating to its end use. TU, Zvolen 
Logemann M, Schelling W (1992) Die Bruchzähigkeit der Fichte und ihre wesentlichen Einflussparameter. Untersuchungen in Mode-I. Holz Roh- Werkst 50(2):47-52

Neuhaus FH (1981) Elastizitätszahlen von Fichtenholz in Abhängigkeit von der Holzfeuchtigkeit. Dissertation, Ruhr-Universität Bochum

Niemz P, Kucera LJ, Pöhler E (1997) Vergleichende Untersuchungen zur Bestimmung des dynamischen E-Moduls mittels SchallLaufzeit- und Resonanzfrequenzmessung. Holzforsch Holzverw 49(5):91-93

Ozyhar T, Hering S, Niemz P (2012) Moisture-dependent elastic and strength anisotropy of European beech wood in tension. J Mater Sci 47:6141-6150

Popper R, Niemz P (2009) Wasserdampfsorptionsverhalten ausgewählter heimischer und überseeischer Holzarten. Bauphysik 31(2):117-121

Pozgaj A, Chonavec D, Kurjatko S, Babiak M (1997) Wood structure and properties, 2nd edn. Priroda, Bratislava

Reiterer A, Sinn G, Stanzl-Tschegg SE (2002) Fracture characteristics of different wood species under mode I loading perpendicular to the grain. Mater Sci Eng, A 332:29-36

Ross RJ (ed) (2011) Wood handbook, 2010th edn. Forest Products Society, Madison
Schmidt J (2009) Modellierung und numerische Analyse von Strukturen aus Holz, Habilitation. TU, Dresden

Sell J (1997) Eigenschaften und Kenngrössen von Holzarten, 4th edn. Baufachverlag, Dietikon

Sonderegger W, Häring D, Joščák M, Krackler V, Niemz P (2012) Untersuchungen zur Wasseraufnahme von Vollholz und Holzwerkstoffen. Bauphysik 34(3):101-106

Sonnabend J (1989) Das Holz des Ahorns und seine heutige Verwendung. Parts 1-2. Holz-Zentralblatt 115:1680, 1683, 2020, 2024

Sonnabend J (1990) Das Holz des Ahorns und seine heutige Verwendung, Part 3. Holz-Zentralblatt 116:26-27

Stanzl-Tschegg SE, Keunecke D, Tschegg EK (2011) Fracture tolerance of reaction wood (yew and spruce wood in the TR crack propagation system). J Mech Behav Biomed Mater 4: 688-698

Szalai J (1994) Anisotropic strength and elasticity of wood and wood based composites, University of West Hungary, Sopron [in Hungarian]

von Wedel K (1964) Untersuchungen über Eigenschaften, Verwertung und Verwendung des Ahornholzes. Dissertation, GeorgAugust-Universität Göttingen, Hann. Münden

Wagenführ R (2007) Holzatlas, 6th edn. Fachbuchverlag, Leipzig 